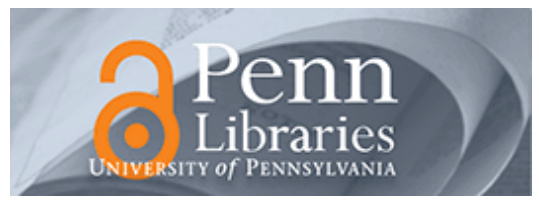

University of Pennsylvania

ScholarlyCommons

Marketing Papers

Wharton Faculty Research

$7-2010$

\title{
eBay's Crowded Evenings: Competition Neglect in Market Entry Decisions
}

Uri Simonsohn

University of Pennsylvania

Follow this and additional works at: https://repository.upenn.edu/marketing_papers

Part of the Advertising and Promotion Management Commons, Business Administration, Management, and Operations Commons, Business Intelligence Commons, E-Commerce Commons, Marketing Commons, Organizational Behavior and Theory Commons, and the Sales and Merchandising Commons

Recommended Citation

Simonsohn, U. (2010). eBay's Crowded Evenings: Competition Neglect in Market Entry Decisions. Management Science, 56 (7), 1060-1073. http://dx.doi.org/10.1287/mnsc.1100.1180

This paper is posted at ScholarlyCommons. https://repository.upenn.edu/marketing_papers/311

For more information, please contact repository@pobox.upenn.edu. 


\title{
eBay's Crowded Evenings: Competition Neglect in Market Entry Decisions
}

\begin{abstract}
Do firms neglect competition when making entry decisions? This paper addresses this question analyzing the time of day at which eBay sellers set their auctions to end. Consistent with competition neglect, it is found that (i) a disproportionate share of auctions end during peak bidding hours, (ii) such hours exhibit lower selling rates and prices, and (iii) peak listing is more prevalent among sellers likely to have chosen ending time strategically, suggesting disproportionate entry is a mistake driven by bounded rationality rather than mindlessness. The results highlight the importance for marketing researchers of assessing rather than assuming the rationality of firm behavior.
\end{abstract}

\section{Keywords}

market entry, marketing, competitive strategy, behavioral economics

\section{Disciplines}

Advertising and Promotion Management | Business | Business Administration, Management, and Operations | Business Intelligence | E-Commerce | Marketing | Organizational Behavior and Theory | Sales and Merchandising 


\title{
EBAY'S CROWDED EVENINGS: COMPETITION NEGLECT IN MARKET ENTRY DECISIONS ${ }^{1}$
}

\author{
Uri Simonsohn \\ The Wharton School \\ University of Pennsylvania \\ Philadelphia, PA19004
}

\begin{abstract}
:
Do firms neglect competition when making entry decisions? This paper addresses this question analyzing the time of day at which eBay sellers set their auctions to end. Consistent with competition neglect, it is found that (i) a disproportionate share of auctions end during peak bidding hours, (ii) such hours exhibit lower selling rates and prices, and (iii) peak listing is more prevalent among sellers likely to have chosen ending-time strategically, suggesting disproportionate entry is a mistake driven by bounded rationality rather than mindlessness. The results highlight the importance for marketing researchers of assessing rather than assuming the rationality of firm behavior.
\end{abstract}

\footnotetext{
${ }^{1}$ A version of this paper, without the theoretical model of section 1.5 is forthcoming in Management Science.
} 


\section{Introduction}

A basic premise of game theory is that agents choose among different courses of action taking into account how the decisions of other agents influence their relative profitability. Firms, for example, are supposed to make entry and production decisions based on residual rather than aggregate demand, taking into account the impact of competitors on the demand they face.

This assumes that firms behave rationally. What may we expect if they were only boundedly-rational? Abundant experimental and survey-based evidence has shown that people exhibit competition neglect, that is, that they tend to choose actions which maximize profits in the absence of competition, but which do not necessarily do so in its presence.

Moore and Cain (2004) find that too many subjects choose to compete on easy tasks and too few on difficult ones (see also Radzevick \& Moore, 2008). Camerer and Lovallo (1999) find that subjects do not adjust behavior sufficiently when competing against self-selected vs. nonself-selected competitors. Real world managers report seeing a small fraction of their actual competitors as rivals (Grisprud \& Gronhaug, 1985; Porac, Thomas, \& Baden-Fuller, 1989), and entrepreneurs report making entry decisions focusing primarily on variables under their own control, mostly ignoring competition (Moore, Oesch and Zietsma, 2004).

In this paper I propose and test a new prediction that arises from applying the notion of competition neglect to the decision firms face as to which of many possible markets to enter; if entrants do not sufficiently take into account the impact of competition, they will tend to erroneously equalize residual demand with aggregate demand disproportionately entering markets with greater aggregate demand. This would lead, for example, to too many restaurants opening in densely populated areas, to too many new radio stations for popular genres, and to too many gadgets being released shortly before Christmas. 
Testing this prediction with non-experimental data is problematic, of course, because markets that differ in aggregate demand also differ in other dimensions that are relevant for both entry and profitability, such as operational costs, barriers to entry, and uncertainty. Furthermore, the goods and services sold across markets that differ in aggregate demand are often heterogeneous themselves. In this paper I examine this prediction of excessive entry into high demand markets in a real market setting that is all but free of such confounds: the time of day at which eBay sellers choose to end their auctions.

Previous research has consistently documented that online auctions receive a high share of bids as they are about to end, ${ }^{2}$ creating a relationship between an auction's ending-time and the demand it faces. The fortune of an auction ending at $8 \mathrm{PM}$ will tend to be determined by bidders who are online in the evening, while that of an auction ending at noon by morning bidders. In other words, as a consequence of last-minute-bidding, eBay consists of multiple quasi-independent sequential markets that differ almost exclusively on their demand levels. If sellers neglect competition, they will tend to disproportionately choose to end their auctions during the times of day when more bidders are online.

I test this prediction with data from 11,796 auctions for best-selling single-DVD movies (e.g., Monsters Inc.), and 3,177 auctions for frequently offered multiple-DVD bundles (e.g., first season of TV show Friends). Consistent with competition neglect, both supply (auctions ending) and demand (bids being placed) peak in the evening, but the peak of supply is significantly more pronounced than that of demand. For example, between 5:00 and 8:59 PM bidders place 25.0\% of their bids, compared to the $37.6 \%$ of all auctions that end during such hours (see Figure 2a). Various analyses suggest that the bidders' peak is exogenous with respect to the behavior of

\footnotetext{
${ }^{2}$ For reviews see section 3 in (Bajari \& Hortacsu, 2004) and section 4 in (Ockenfels, Reiley, \& Sadrieh, 2006)
} 
sellers (e.g., visits to Amazon.com have a very similar pattern and bidder experience is uncorrelated with time-of-day at which bids are placed).

Sellers' disproportionate entry has consequences: their profits are lower during peak bidding hours. An average seller listing her auction at around noon rather than around 8PM, for example, would increase her odds of selling a single-DVD by 13 percentage points and increase its expected price by about 38 cents (a $4 \%$ increase). For a DVD bundle the consequences would be a 5 percentage point increase in probability of sale and $\$ 3.40$ in final price (a $6 \%$ increase). Given how competitive the market for DVDs is, these price effects are likely to constitute a significant share of the profits sellers take home. ${ }^{3}$

I interpret such disproportionate entry into, and lower profits during peak bidding hours as evidence that competition neglect influences both eBay sellers' decisions and market outcomes. The most plausible alternative explanation relies on listing costs. In particular, considering that eBay auctions end at the same time of day as when sellers list them, if listing during peak bidding hours is more convenient (less costly), then sellers may willingly accept a lower expected profit for listing at such times.

Several additional analyses suggest this explanation does not account for the excessive entry results. For example, sellers who pay a fee that allows them to change the default endingtime of their auction, end a higher share of their auctions during the peak (48\%) than sellers not paying the fee do (37\%). Also, subsets of sellers that should be less influenced by the convenience of early-evening listing, such as stores, sellers listing on a weekend, and sellers

\footnotetext{
${ }^{3}$ The first version of this paper only contained the single-DVD sample and found only an effect on probability of sale. While working on a separate paper, \{Simonsohn, Forthcoming \#892\}, I improved the algorithm to identify eBay items based on sellers' description. After cleaning the dataset with this new algorithm the price effect became significant. For robustness I created the DVD-bundles sample, replicating the effect on prices.
} 
listing more expensive items, all end a similar share of their auctions during peak hours as the rest of sellers do.

Furthermore, collecting information from books giving advice to eBay sellers I obtained anecdotal evidence that supports the competition neglect interpretation of the data. In particular, I find that of 26 books consulted the vast majority making an ending-time recommendation makes it based on aggregate demand, fully neglecting the role of competition. The notable exception are two books who indicate that while peak hours are attractive because there are more consumers around, there are also more competitors and so they advice their readers to avoid listing their items in the peak.

One concern with studying entry decisions with auction data is the question of whether eBay sellers are in fact firms who seek to maximize profits (rather than individuals, say, getting rid of unwanted items). This issue is discussed in some detail in the Conclusions section, but it is worth mentioning here that a sizeable share of items in the data are listed by large sellers and that, furthermore, such sellers are more rather than less likely to excessively end their auctions during the peak-demand period. In fact, additional analyses suggest that the excessive entry into peak-bidding hours is driven primarily by professional sellers, not individuals.

In documenting sellers' failure to take into account relevant factors when making decisions this paper is related to a growing empirical literature studying inattention. Recent research, for example, has shown evidence of inattention to non-saliently displayed prices (Hossain \& Morgan, 2006; Lee \& Malmendier, 2008; Simonsohn \& Ariely, 2008), to information that competes with attention-grabbing or abundant information (DellaVigna \& Pollet, 2009; Eisensee \& Strömberg, 2007; Hirshleifer, Lim, \& Teoh, forthcoming) and to future 
events occurring beyond immediate planning horizons (Che, Sudhir, \& Seetharaman, 2007;

DellaVigna \& Pollet, 2007). 
More broadly, it is also related to a growing literature that employs field data to study psychological findings that are relevant for marketing researchers, such as the prominence effect (Hsee, Dube, \& Zhang, 2008), contrast effects (Simonsohn, 2006; Simonsohn \& Loewenstein, 2006) and the should/want distinction for consumer goods (Milkman, Rogers, \& Bazerman, 2009). For a review of the closely related literature of behavioral economics with field data see

(DellaVigna, forthcoming). Finally, in studying bounded rationality in a market entry setting this paper is related to (Goldfarb \& Xiao, 2008; Goldfarb \& Yang, Forthcoming) who apply structural bounded rationality models to market entry decisions and study the correlates of imputed strategicness in entry behavior across firms.

\subsection{Theoretical Framework ${ }^{4}$}

In this section I put forward a framework where sellers decide in which of two time periods, with different levels of aggregate demand, to enter a market. After establishing the equilibrium for fully rational agents, I explore the consequences of (some) sellers exhibiting competition neglect employing Camerer, Ho and Chong (2004)'s Poisson-Cognitive-Hierarchy model.

Setup

Consider a three-period market for a commodity, with $B$ buyers and $S$ sellers. In period -1 buyers choose whether to enter during period 0 or 1 , and sellers, after observing the decisions of buyers, independently decide which period to enter.

\footnotetext{
${ }^{4}$ I number this section 1.5 so that the rest of structure of this paper matches the version accepted for publication at Management Science. That version does not contain the model presented here.
} 
Let $q_{b}$ and $q_{s}$ represent the proportion of buyers and sellers, respectively, entering period $1 . q_{b}$ is exogenously determined, with $q_{b}>.5$, indicating that demand peaks during period 1 (the empirical analyses support the assumption of demand's exogeneity for the current setting of interest).

Each seller owns, and each buyer is interested in buying, a single unit of the commodity. Buyer $i$ values it $v_{i}$, distributed according to the cumulative distribution function $V$, such that $\operatorname{Prob}\left(v_{i} \leq p\right)=V(p)$. Similarly, the commodity costs seller $j c_{j}$, distributed $C$, such that $\operatorname{Prob}\left(c_{j} \leq p\right)=C(p)$.

\section{Equilibrium}

The equilibrium price in each period equalizes quantities supplied and demanded. Considering that a buyer will not pay more than her valuation and that a seller will not sell for less than her cost, and denoting equilibrium prices for periods 1 and 0 with $p_{1}^{*}$ and $p_{0}^{*}$ respectively, the equilibrium conditions are:

$$
\begin{aligned}
& \mathrm{Bq}_{\mathrm{b}}\left(1-\mathrm{V}\left(p_{1}^{*}\right)\right)=\mathrm{Sq}_{\mathrm{s}} \mathrm{C}\left(p_{1}^{*}\right) \\
& \mathrm{B}\left(1-\mathrm{q}_{\mathrm{b}}\right)\left(1-\mathrm{V}\left(p_{0}^{*}\right)\right)=\mathrm{S}\left(1-\mathrm{q}_{\mathrm{s}}\right) \mathrm{C}\left(p_{0}^{*}\right)
\end{aligned}
$$

In addition, for the market as a whole to be in equilibrium, there must be no price differences across periods, i.e. $p_{0}^{*}=p_{1}^{*}$. Dividing (1) by (2) and applying $p_{0}^{*}=p_{1}^{*}$ we obtain that the equilibrium seller entry-rate into the peak demand period is $q_{s}^{*}=q_{b}$. In words, if the share of sellers entering each period equals the share of buyers entering them, the market will be 
in equilibrium. Note that if $q_{s}>q_{b}$ then $p_{1}<p_{0}$, i.e. if more than the equilibrium share of sellers enter in period 1 , prices are lower in period 1 than in period 0.

\section{Introducing competition neglect}

For an equilibrium to be attained sellers must behave as-if they held accurate beliefs about the actions of other sellers. In the presence of competition neglect, however, sellers underweight the impact of the actions of others on their own payoffs. If all sellers were to fully neglect competition, all sellers would choose based exclusively on aggregate demand and enter period 1 (i.e., $q_{s}=1$ ), leading to a low price in period 1 and to no transactions in period 0.

A more realistic prediction arises if we allow sellers to be heterogeneous in how strategic they are. An increasingly popular approach for modeling such heterogeneity consists of categorizing players according to a hierarchy of types indexed by levels, where a type's level indicates how cognitively sophisticated she is (see e.g. Binmore 1988; Camerer et al. 2004; Crawford and Iriberri 2007; Gneezy 2005; Nagel 1995; Stahl 1993; Stahl and Wilson 1994). In such 'Cognitive Hierarchy' models, level-0s choose non-strategically, level-1s best respond to the random behavior of level-0s, level-2s best-respond to a mix of level-0s and level-1s and so on.

Camerer Ho and Chong (2004) put forward the Poisson-Cognitive-Hierarchy model (PCH). It assumes that (i) agent types are distributed according to a Poisson-distribution ${ }^{5}$, (ii) agents believe that all other agents are less sophisticated than they are, (iii) level-0s employ a uniform distribution to draw from the action space, and (iv) agents have accurate beliefs about

\footnotetext{
${ }^{5}$ That is that the frequency of agents who are level-k, $\mathrm{f}(\mathrm{k})$, is determined by the distribution $f(k)=e^{-\tau} \tau^{k} / k !$, where $\tau$ is the free parameter in the Poisson distribution..
} 
the relative frequencies of those less sophisticated than them (e.g. level-2s have accurate beliefs about the relative share of level-0s \& level-1s), ${ }^{6}$

Given the PCH's parsimoniousness, in that its only free parameter is that from the Poisson distribution of types, I employ it here to consider the consequences of competition neglect in a market-entry setup. Note that assumptions (ii) \& (iv) above introduces competition neglect because level-k sellers behave as if there were no other level-ks.

Applying the $\mathrm{PCH}$ to the previous framework is straightforward. Let $\mathrm{q}_{\mathrm{s}, \mathrm{k}}$ represent the share of level-k sellers entering period 1. By assumption $\mathrm{q}_{\mathrm{s}, 0}=.5$ (level-0s choose uniformrandom). Because level-1s believe that everyone else is a level-0, i.e. because they neglect the competition of other level-1s and of higher levels, they all respond to the level-0s' insufficient entry into period 1 by entering such period themselves, i.e. $\mathrm{q}_{\mathrm{s}, 1}=1$.

Which period is perceived as more profitable by level-2s is a function of $q_{b}$ and of the relative share of level-1s and level-0s (and hence of the free parameter in the Poisson distribution). In particular, level-2s will enter period 1 if the combined share of level-1s and level-0s in it is smaller than the share of buyers in it. Letting $\mathrm{f}(\mathrm{k})$ represent the relative frequency of level-k agents, this is equivalent to level-2s entering period 1 if $\frac{f(0) * .5+f(1) * 1}{f(0)+f(1)}<q_{b}$. The actions of level-3s and above are similarly determined by solving the recursive problem of what lower types do. The market as a whole will exhibit excessive entry into the peak period if the number of level-2s (and above) is insufficient to correct for the excessive entry of lower levels.

\footnotetext{
${ }^{6}$ Camerer et al. acknowledge that the assumption of level-0s drawing actions at random from a Uniform distribution is made only for the sake of simplicity and that it "is a placeholder assumption which could easily be relaxed in later research" (p.864). In the empirical section I relax this assumption and find that a more plausible one leads to very similar results. Intuitively, as long as level-0s insufficiently enter the peak period, the main qualitative results hold because level-1 excessively enter it regardless of the magnitude of insufficient entry. This relative lack of sensitivity to assumptions about level-0s are, however, need not be very general. (Crawford and Iriberri 2007), for instance, finds that the predictions of the model are entirely dependent on what's assumed level-0s do.
} 
In other words, the model predicts excessive entry into the peak demand period if the share of level-2 and above is insufficient to cancel-off the mistakes of level-1s.

In sum, a rational-seller model predicts entry into the peak period that's proportional to demand. A Cognitive-Hierarchy model, and the $\mathrm{PCH}$ in particular, is consistent -for certain parameter values- with excessive entry into the peak period. This excessive entry occurs because sellers exhibit competition neglect; they enter the peak-period realizing that lower types are insufficiently serving it, but neglecting that other agents of the same sophistication are arriving at the same conclusion.

\section{Data Description and the Disproportionate Entry Pattern}

Although many eBay sellers are individuals who sell sporadically, eBay is progressively attracting sellers who use eBay to sell large numbers of items. Indeed, many stores use eBay as their main distribution channel for both new and used items. Over half the items in the sample used in this paper, for example, were listed by sellers listing at least 300 DVDs during the first 9 months of 2002 .

By default, auctions end at the same time of day as when sellers list them. For example, suppose a seller sets up a three-day auction at 10:17AM on Monday; this auction would start immediately and end on Thursday at 10:17AM. Sellers have an option to pay a 10-cents scheduling fee that allows them to start (and hence end) their auction at a time other than when they list it. ${ }^{7}$

\footnotetext{
${ }^{7}$ All times reported in the paper are Pacific Standard Time (PST).
} 


\section{The Dataset}

Data description. The raw dataset contains information on over 500,000 auctions, and their corresponding over 1.2 million bids, encompassing all auctions taking place in October of 2002 in the DVD-movie category. Because eBay does not employ product-codes that uniquely identify items being auctioned (e.g., UPCs or ISBNs), bidders and researchers must rely on sellers' descriptions of their items to identify the products being auctioned. For this reason I conducted an item identification process, described in detail in the appendix, to create two subsamples. One contains single-DVD movies that were listed as weekly best-sellers at IMDB.com at least once during the ten weeks preceding the sampling period (e.g., the film " $A$ Beautiful Mind"), and the other contains common multiple-DVD packs (e.g., the first season of the TV show " $24 "){ }^{8}$

Descriptive Statistics. Table 1 shows overall means, medians, and standard deviations for variables used in the analyses that follow, tabulated separately for both subsamples. Auctions for single-DVDs have lower prices, probabilities of sale and number of bids than multiple-DVD ones.

\section{$* * *$ Table $1 * * *$}

The samples combined contain auctions from 4,513 different sellers. The single seller with the greatest market share offered about $2.4 \%$ of all auctions, and the largest ten sellers combined just under 16\%; eBay auctions for DVDs are not a highly concentrated market.

\footnotetext{
${ }^{8}$ The excessive entry pattern is observed not only in these subsamples of relatively high frequency items, but in the overall dataset of DVD auctions. In particular, in the full dataset $25 \%$ of bids are placed during the peak, but $34.5 \%$ of all auctions end during such hours.
} 


\section{Late Bidding}

As mentioned in the introduction, a number of papers have shown that a substantial share of bids arrive as auctions are about to end. The auctions in this sample are no exception. Over $60 \%$ of winning bids arrive with less than 3 hours left in the auction and fully $18 \%$ of them during an auction's last minute.

Given that a key premise in this paper is that last-minute-bidding creates a link between an auction's ending-time and the bidders that end up determining its fate, it is necessary to assess the prevalence of last-minute bidding through the day. Figure 1 plots the percentage of auctions, by hour at which they end, that received their winning bid during their last 180 minutes (auctions not resulting in a sale are excluded from the figure). The figure shows that late bidding is relatively stable through the day. Early auctions do show somewhat less late bidding but fewer than $8 \%$ of auctions depicted in Figure 1 end before 7AM. In sum, Figure 1 suggests that indeed an auction's ending-time is likely to strongly influence the bidders it faces and that such link is more or less stable through the day.

$$
* * * \text { Figure } 1 * * *
$$

\section{Timing of bids and auctions}

Figure 2 a plots the percentage of daily auctions ending, and of bids placed, by hour. Multiple bids by the same bidder are excluded, keeping only a bidder's last bid (this is the time when the bid was actually placed, excluding automatic revisions by eBay's proxy bidding system).

The figure shows that the frequency of new bids increases consistently through the day until reaching a peak at around 5PM, and then it slowly declines till the end of the day. Auctions show a qualitatively similar pattern. 
Consistent with competition neglect, however, where sellers would choose the endingtime of their auction at least partially ignoring competition, the auction's peak is much more pronounced than that of bids'. Between 5:00PM and 8:59 PM bidders place 25\% of their bids, while sellers set $37.6 \%$ of their auctions to end. In other words, during the peak bidding hours we observe roughly $50 \%$ more auctions than we would expect to observe if entry was proportional to demand. The greater fraction of auctions taking place during the peak than of bids being placed during such hours is, not surprisingly given the number of observations involved, statistically significant: $Z=28.29, p<.0001$.

\section{$* * *$ Figure $2 * * *$}

The hourly ratio of the percentage of auctions ending to the percentage of bids being placed provides an intuitive sense of how seller-saturated different times of the day are. Figure $2 \mathrm{~b}$ displays how this ratio changes through the day (with SE computed via the delta method). At 8PM, for example, the most saturated hour in the sample, the ratio of percentage of daily auction ending to percentage of daily bids being placed is 1.79 , compared to .84 at noon. This means that there are more than twice as many auctions per bid at $8 \mathrm{PM}$ as there are at $12 \mathrm{PM}$. To assess the statistical significance of the negative association between aggregate demand and residual demand I estimated a regression using one observation per hour (i.e. $N=24$ ), with the A/B-ratio during that hour as the dependent variable and the share of daily bids placed during such hours the sole predictor. In line with Figures $2 a$ and $2 b$, the estimated relationship is positive and significant $(\beta=.131, \mathrm{SE}=.031, \mathrm{p}<.01){ }^{9}$

\footnotetext{
${ }^{9}$ As pointed out by a referee, each observation in this regression is a 'generated regressor' because they are hourly averages across the 31 days in the sample, but the sampling error in such averages is ignored in the regression. One
} 


\section{Are the peaks strategic?}

This paper studies how sellers respond to daily variation in demand, assuming that the timing of bids is exogenous. In what follows I first assess the validity of this premise and then look more closely at how strategic seller-behavior is.

Demand's peak. One way to assess if the actions of sellers influence the time of day at which bidders participate on eBay is to compare the timing of eBay bids through the day to the distribution of visits to other shopping-related websites, where time plays no strategic role.

To conduct this comparison I obtained data from comScore Inc., a panel of 2,000,000 internet users. In particular, I downloaded data from a random sample of 100,000 users, available from Wharton Research Data Services (http://wrds.wharton.upenn.edu), and computed the percentage of daily visits to Amazon.com by hour (employing data also from October of 2002). According to these data, $25.9 \%$ of visits to Amazon.com took place between 5:00PM and 8:59PM, a figure that is quite similar to the $25.0 \%$ of eBay bids being placed at such hours. Moreover, the correlation between hourly visits to Amazon.com and hourly bids on eBay, computed with 24 observations -one for each hour of the day- is a striking $r=.98$.

Another approach is to consider bidders' experience. We might expect that bidders with more experience become more strategic. Simonsohn \& Ariely (2008), for instance, find that experienced bidders learn not to herd behind non-diagnostic bids. If the timing of bids was a strategic decision, then it would be expected to be influenced by experience. Figure 3 depicts the share of bids placed between 5:00 and 8:59 PM as a function of bidder experience (as proxied by

way around this problem is to estimate the regression with the full set of 744 hours in the month as observations. With this specification the qualitative nature of the results does not change $(\beta=.107, p<.001)$. A two-stage estimator where in the first stage the percentage of daily bids is instrumented with hour dummies also leads to similar results $(\beta=.106, \mathrm{p}<.001)$. 
their bidder rating). The flat line for bidders shows that experience is not associated with the tendency to bid during peak bidding hours (the impact of experience on sellers is discussed later).

Another indication that bidders are not choosing their bidding time strategically is that, as we saw earlier, late-bidding does not fluctuate much through the day (see Figure 1). If bidders were actively responding to supply changes through the day, they would be expected to vary the likelihood of bidding on auctions that are ending soon, as a function of how saturated the time of day at which they are visiting eBay is, but they do not.

Finally, none of the advice books, discussed in detail later, nor any of the online bulletin boards I informally visited to address this question, make explicit recommendations about the time of day at which bids should be placed.

Supply's peak. Because auctions end by default at the same time of day as when they are listed, it is possible for sellers to "choose" ending-times without thinking about it. It is hence conceivable that the pattern of excessive entry is the result of mindlessness rather than of competition neglect per-se. To address this issue empirically, I assessed whether sellers inferred to be making ending-time decisions intentionally/strategically are more likely to end their auctions during the peak.

Intentionality, unfortunately, is of course unobservable, but I employ the following four alternative proxies for it: (i) paying a scheduling fee to opt-out of the default ending-time, (ii) choosing a rounded ending-time (e.g. 10.00AM rather than 9:59 or 10:01), (iii) consistently choosing similar ending-times for different auctions, and (iv) seller experience. As we shall see, all four proxies lead to results consistent with the disproportionate entry pattern being driven by a conscious yet mistaken logic rather than by random carelessness. 
(i) Scheduling fee. Sellers paying this fee must explicitly set an ending-time (they must type it into a textbox) so they are less likely (if at all) to list an auction without thinking about its ending-time. Consistent with sellers choosing to disproportionately enter the peak, a higher share of auctions listed with a scheduling fee end during the peak (48\%) than of auctions listed without it (36\%). Though the difference is quite marked, very few auctions were listed using this scheduling fee (around 1.6\%), perhaps because sellers can determine the ending-time of their auction for free by listing their item at the desired time, or by using software that will automatically list for them at a predetermined time.

(ii) Rounded ending-times. Considering that people actively choosing a time-of-day are likely to choose rounded times, roundedness may act as a proxy for sellers having actively chosen an ending-time.

I tested the face validity of this assumption by assessing how prevalent rounded times were among auctions listed using the scheduling fee just discussed. A striking $44.4 \%$ of scheduled auctions ended in xx:00 or xx:30, compared to just $4.1 \%$ of those listed without the scheduling fee. In the single and multiple-DVD samples, 5.2\% have a rounded ending-time, $46.8 \%$ of these end during the peak, a noticeably higher share than the $37.1 \%$ of non-rounded ones. Excluding auction listed with the scheduling fee these figures are $41.7 \%$ and $36.8 \%$ respectively.

(iii) Consistency. Sellers who systematically choose the same ending-time for their auctions are more likely to be doing so intentionally. Unlike the previous two proxies this one can be applied to most sellers in the sample (only sellers with few auctions are excluded) but it is a noisier proxy, as sellers may intentionally spread out their auctions or they may cluster them due to external constrains. 
To quantify consistency of ending time I used a seller's average deviation of ending-time across auctions (taking into account that time is reset daily, that is, that between $11.59 \mathrm{PM}$ and 12:01AM there are just 2 minutes rather than 23 hours and 58 minutes). I use variance in one half of the month to predict ending-time decisions in the other half with the full dataset of DVD auctions. Sellers with less than 5 auctions in one half of the month were excluded from this analysis (the results do not vary if I exclude instead sellers with less than 3 auctions in one half of the month, or with less than 10). Figure 4 plots sellers' average percentage of auctions ending during the peak demand period of 5:00PM to 8:59PM by sellers' decile of standard deviation in ending times. It shows that sellers with lower standard deviations (in one half of the month) are more likely to set the ending time of their auctions during the period of peak demand (in the other half). For example, sellers who are in the lowest decile of variation set around 39\% of the auctions during the period of peak demand, while those in the highest decile do so for just $27 \%$ of them.

\section{$* * *$ Figure $4 * * *$}

(iv) Experience: The fourth variable used to proxy for intentionality is experience. As was argued with bidders, one would expect that experience increases the prevalence of strategic behavior among sellers. Figure 3 plots share of auctions listed during the peak as a function of seller experience; it shows a marked increase in sellers' tendency to end auctions during peakbidding hours as a function of experience. This result is again consistent with the notion that the sellers responsible for excessive entry are those that are most likely to be strategically choosing the end-time of their auction. 


\section{Convenience as an alternative explanation}

In this section I consider the possibility that the disproportionate share of auctions ending during the peak is caused by the greater "convenience" associated with listing items at such hours. Considering that by default an auction's ending time coincides with the time of day at which it is listed, if listing during peak hours is less costly, then it may be optimal for a disproportionate share of sellers to do so, even if -as we shall see in the next section- it leads to lower probability of sale and prices.

The assumption on which such story relies is reasonable, listing costs may very well vary through the day as a function, for example, of the opportunity cost of time. Note, however, that to explain a more pronounced peak for auctions, the listing cost explanation requires that for sellers the costs differences through the day are steeper than for bidders.

A listing cost based explanation leads to several testable predictions. First, sellers who would be expected to face flatter listing costs through the day, such as stores, large sellers, and sellers listing on weekends, should exhibit a less pronounced peak. This, however, is not the case as these subsets of sellers end $38 \%, 45 \%$ and $34 \%$, respectively, of their auctions during the peak (compared, recall, to $37.6 \%$ of all auctions, and $25 \%$ of bids).

Similarly, since the (differential) cost of listing an item during peak demand hours is probably not dependent on the value of the item being listed, more expensive items should be more likely to be listed off-peak (since the benefits of doing so are greater but the costs constant). More expensive items do show some attenuation in peak-entry, but it is quite slight. For example, $32 \%$ of items starting at $\$ 30$ or above end in the peak, and $33 \%$ of those starting above $\$ 60$ do. 
Finally, sellers who paid the scheduling fee face a constant cost of ending an auction at any time of the day and should therefore exhibit the least peak listing of all, but as was reported above, they show a more pronounced peak ( $48 \%$ of such auctions end in the peak).

An alternative explanation closely related to the listing costs one is that sellers may want to be around when an auction ends, and being around during peak demand hours may be more convenient. This explanation makes the same predictions as the listing cost explanation, with the exception that scheduled auctions would not need to show a less pronounced peak. It makes the additional prediction that auctions ending on a weekend would be less likely to end during the peak, but $36 \%$ of them do.

\section{Excessive Entry’s Impact on Profits}

This section presents results estimating the consequences for probabiliy of sale and selling prices of listing an item during periods of peak vs. off-peak demand. I present results for three alternative measure of peak-listing. The first is a set of 23 hourly dummies. Their main advantage is that they create an intuitive and easy to display result. Indeed, I plot the point estimates for these dummies in Figures 5 and 6, creating an easy to visualize daily pattern in probabilities of sale and expected final prices. Their main disadvantage, on the other hand, is that it is difficult to compare the impact on so many different point estimates of controlling (vs. not) for observable heterogeneity. For this reason I also present regression tables that use a single key independent variable as a predictor. I consider two: ratio of the percentage of daily auctions ending over the percentage of daily bids being placed during an auction's last 180 minutes (A/B-ratio), and a peak-dummy which equals 1 if an auction ends during one of the four most popular hours of the day and 0 otherwise. 
In all regressions auctions are the unit of observation. For the probability of sale regressions I estimate Probit regressions. For the price estimates I run both Tobit and OLS regressions. The OLS regressions include only sold items, while the Tobit regressions include all items and treat unsold ones as censored at the starting price.

Figures 5 and 6 plot the results of the regressions that employ hourly dummies as predictors. Figure 5 has the results for the Single-DVD sample and Figure 6 for the MultipleDVD one. In both figures the bold discontinued lines show the A/B-ratio computed on the respective sample. ${ }^{10}$ The solid black lines depict marginal effects for the hourly dummies from the Probit regressions, while the solid gray lines depict the marginal effects from the Tobit price regressions. The Tobit marginal effects were computed for final prices conditional on them being above the auction's staring-price/censoring-point (i.e. $\mathrm{E}\left(\mathrm{y} \mid \mathrm{XB}, \mathrm{y}>\mathrm{y}_{\min }\right)$. All marginal effects are computed at sample means.

In Figure 5 both solid lines show a marked drop that coincides with the peak of the discontinued one: at times of day when sellers disproportionately enter the single-DVD market, both prices and probability of sale show a marked decrease. Prices around 8PM, for instance, are $\$ 0.38$ lower than around noon, and probability of sale is around 14 percentage points lower. The sample averages for these are $\$ 10.16$ and $71 \%$ respectively.

In Figure 6 the overall pattern is quite similar; here too both probability of sale and prices drop at the times of day when sellers are disproportionately ending their auctions. Prices around 8PM, for example, are $\$ 3.40$ lower than around noon, and probability of sale is about 5 percentage points lower; the respective sample means are $\$ 55.9$ and $90 \%$ respectively. ${ }^{11}$

\footnotetext{
${ }^{10}$ In order keep the graph with just $2 \mathrm{Y}$-axes, the A/B-ratio was rescaled by adding a constant to it. Neither axis in the graph represents the actual values of the A/B-ratio.

${ }^{11}$ Between 12AM and 1 AM there are just 49 multiple-DVD auctions; the point estimates for the corresponding hourly dummies in the price regression are hence very noisy and were not included in Figure 6 to improve
} 
***Figures 5 and $6 * * *$

To present the impact of the other covariates on the dependent variables and to assess the impact of the inclusion of such covariates on the point estimates for the key independent variable I now turn to the regressions that employ a single predictor rather than the 23 hourly dummies.

When using the A/B-ratio as a predictor, in order to identify the impact of ending time on auction outcomes that operates only through predictable variation in it (rather than of contemporaneous shocks which sellers could not anticipate), instead of employing as a regressor the A/B-ratio of the time when auctions actually end, I used the average ratio for that same time for all other days in the sample. For example, the outcome of an auction ending on Tuesday October $8^{\text {th }}$ at $8.45 \mathrm{PM}$ was predicted with the average $\mathrm{A} / \mathrm{B}$-ratio between $5: 46 \mathrm{PM}$ and $8: 45 \mathrm{PM}$ for all other working days in October. Due to some differences in the timing of auctions and bids between samples, and between working and non-working days, the average A/B-ratio was computed separately for each of these four subsets of auctions. ${ }^{12}$

I estimated probit regressions with auctions as the unit of observation. The dependent variable equals 1 if an item sold and 0 otherwise, and the key predictor is A/B-ratio. The

readability. The missing values are $\Delta \mathrm{Y} / \Delta \mathrm{X}_{12 \mathrm{AM}}=-\$ 6.56, \Delta \mathrm{Y} / \Delta \mathrm{X}_{1 \mathrm{AM}}=-\$ 8.27$. Also, to provide a reliable comparison between $8 \mathrm{PM}$ and noon I compare the average marginal effect between 7-9PM with the average between 11AM-1PM rather than then single estimate at 8PM and 12PM.

${ }^{12}$ In line with the discussion prompted by a referee of generated regressors in footnote 4 , because the A/B-ratio is an average, its sampling error should be considered when computing the standard errors of the regressions described above, but it is not. To assess the importance of this problem I compared the standard errors obtained with a linear probability model where the ratio is entered as a predictor (ignoring its sampling error) with those obtained with a 2SLS where in the first stage the A/B-ratio is estimated based on hourly dummies, and the second stage uses the predicted $\mathrm{A} / \mathrm{B}-$ ratio, taking into account its sampling error, to predict probability of sale. The resulting standard errors are about $5 \%$ lower in the two-stage regression, suggesting the impact of the generated regressor's sampling error is trivial. For simplicity of exposition I report the results from the one-stage estimators. Note that the peakdummy (used columns 4 and 8 ) is not a generated regressor. 
regressions also include the various controls for movie, auction design and seller observable differences mentioned above.

Table 2 displays the results, expressed as marginal effects (i.e. as changes in predicted probability of sale as the independent variable is increased in 1 unit). Columns 1-4 show the results for the single-DVD sample and columns 5-8 for the multiple-DVD sample. The bottom row in the table displays the estimated impact on probability of sale of ending the auction during a peak vs. off-peak hour, in order to make the results obtained through the multiple specifications easy to compare.

\section{$* * *$ Table $2 * * *$}

The point estimate for A/B-ratio is negative in all columns and it is significant in all of them as well, with the exception of column 5 (multiple-DVD sample, without covariates); consistent with Figures $5 \& 6$ this indicates that at times of day when there are relatively more auctions per bid a systematically smaller share of auctions sell. The effect of A/B-ratio does noticeably attenuate as controls are added to the regression in the single-DVD sample $\left(\beta_{(1)}=-.355, \beta_{(3)}=-.289\right)$, but it is augmented in the multiple-DVD sample $\left(\beta_{(4)}=-.125\right.$, $\left.\beta_{(6)}=-.243\right)$, alleviating concerns that the results might be driven by omitted variable bias.

Focusing on the bottom row which contains the marginal effect of ending an auction in the peak vs. off-peak, we see that ending an auction in the peak drops probability of sale by about $6-7 \%$ in the single DVD sample, and by about $4 \%$ in the multiple DVD sample. Note that the marginal effects estimated with the peak-dummy (columns 4 and 8 ) are very similar to those obtained with the A/B-ratio.

The marginal effects for all other variables are as would be expected; auctions with lower starting and reserve prices, with lower shipping and lasting more days, and those listed by more 
experienced sellers are all more likely to sell. The sole surprising result is that of the store dummy which is negative, indicating that sellers who have a contractual agreement with eBay are less likely to sell their auctions. The effect of store controlling for reputation (log(seller rating)), however, is hard to interpret, as one might expect that being a store improves a seller's performance through reputation. If the regression is estimated without controlling for reputation, the marginal effect of store is positive and significant.

To estimate the impact of ending-time on selling price I estimated regressions with auctions as the unit of observation. The dependent variable equals the selling price for sold auctions and, in the Tobit specifications, the starting-price for non-sold/'censored' ones.

The results of these regressions are displayed in Table 3. For the Tobit specifications I report marginal effects on price conditional on sale $\left(\mathrm{E}\left(\mathrm{y} \mid \mathrm{XB}, \mathrm{y}>\mathrm{y}_{\min }\right)\right.$. Robust standard errors are reported below point estimates. Columns 1-5 show the results for the single-DVD sample and columns 6-10 for the multiple-DVD sample. The bottom row in the table displays the estimated impact on selling prices caused by ending the auction during a peak vs. off-peak hour to facilitate comparison across columns and to provide an intuitive sense of the practical significance of the results.

The point estimate for the A/B-ratio (and for the peak dummy) is negative and significant at the $1 \%$ level across all columns. The effect of A/B-ratio is estimated as larger for both samples when observable heterogeneity is vs. is not controlled for, suggesting these results are not due to omitted variable bias. ${ }^{13}$

\footnotetext{
${ }^{13}$ As was discussed in footnote 7, the A/B-ratio is a generated regressor and hence the true standard errors may be larger than those estimated in Table 3. As was done with the pr(sale) regression I assessed the potential importance of this problem with a 2-stage regression where in the first stage the ratio is regressed on hourly dummies. Here the standard errors are about $5 \%$ higher in the two-stage estimation, the change does not alter the significance of the point estimates.
} 
The marginal effects for all other predictors in Table 3 are as would be expected; auctions with higher starting-prices and reserve prices, those with lower shipping and lasting more days, and those listed by more experienced sellers are all more likely to sell. The sole surprising result is again the store dummy which is negative, but also here it becomes positive if the regression is estimated without controlling for seller reputation.

\section{***Table $3^{* * *}$}

\section{Expert advice on eBay books}

The growing popularity of eBay has lead to a proliferation of publications dedicated to help both buyers and sellers who participate on it. The recommendations printed in these books can safely be assumed to consist of an upper bound of the typical eBay seller's sophistication, as "experts" presumably write them. If people writing books about eBay fail to take into account how the actions of other sellers influence the profitability of different ending times, it seems particularly plausible that eBay sellers in general fail to do so as well.

A research assistant (blind to the hypothesis of this paper) collected and summarized ending-time recommendations from all (26) eBay books available at two local bookstores. Books were then categorized as giving no recommendation, or as giving one based on aggregate or residual demand.

Eight books did not mention ending-time, or considered neither demand nor supply in their recommendation. Fourteen books make a recommendation based on aggregate demand alone and hence fall prey to competition neglect. For example, the book "eBay Strategies" (Wingo, 2004) has the following recommendation "Timing your auctions to end during peak 
times will significantly improve traffic to your auctions, resulting in more bids" (they then recommend 5-9 PM PT).

Only two books took into account competition when making ending-time recommendations. For example the aptly titled eBay Myth-Buster (Busch, 2004) states "If selling a fairly common item, high-traffic nights might be the absolute worst time to close (too much competition)". ${ }^{14}$

The content of the eBay books, in sum, supports the interpretation given to the excessive entry pattern: all advice is a function (only) of demand considerations and primarily only of aggregate demand. This means that, on the one hand, eBay sellers literally engage in competition neglect rather than simply behave as if they did, and on the other, that none of the alternative explanations I consider (or any I don't for that matter) are even mentioned by eBay experts (e.g., no book suggests listing in the evenings because it is more convenient to do so, or that bidders choose bidding times based on when the most auctions are ending).

\section{Conclusions}

Based on the experimental and survey based literatures documenting competition neglect, i.e. players' tendency underestimate the impact of their competitors' actions, I hypothesized that firms would tend to over-supply high-demand markets. Exploiting the fact that bidders bid last-minute on online auctions, creating sequentially and at least partially independent markets, I tested this hypothesis by studying the ending-time decisions of eBay sellers. As predicted, a disproportionate fraction of them end their auctions during peak hours, leading to lower probability of sale and final prices during such hours. This excessive entry

\footnotetext{
${ }^{14}$ Two books gave ambiguous advice which could not easily be classified.
} 
appears to be driven by the subset of sellers who intentionally choose ending times, rather than by those who do so mindlessly.

Studying the prediction of excess entry into high demand markets within the context of the timing of auctions for commodities has two notable advantages. The first is that, unlike most other settings, markets here differ only in their demand levels, making comparisons of outcomes across markets much easier to interpret; there are no potential confounds of entry costs, required expertise, uncertainty, and so on. The second advantage is that, again unlike most other settings, by studying the performance of a commodity, counterfactual outcomes for items offered in one market are available from other markets, and hence one can estimate with a high degree of certainty what a seller would have obtained had she entered a different market.

The chosen setting, however, is of course not free of disadvantages. In particular, although determining the time-of-day to end an auction is in theory analogous to a market entry decision, there are noticeable differences between them in practice. Most notably, the decisions studied here are repetitive and for relatively small-stakes, while market entry decision are typically infrequent and for very large stakes. Similarly, market entry decisions are made by a few "experts" or entrepreneurs, while ending-time decisions are made by individual sellers (though many of them are firms).

There are two points worth considering with regards to these limitations. The first is that agents making repetitive decisions would be expected to act more rationally than those making one-off decisions, by virtue of having had more opportunities to learn from feedback. The second is that in the data used here, larger sellers were more rather than less likely to exhibit competition neglect. 
Another concern with the present study is the possibility that DVDs are an odd product for eBay. In particular, if it is typically the case that goods sold on eBay do not have close substitutes, then ignoring competition may be a fine strategy for most sellers most of the time. On eBay, however, goods with substitutes are the norm rather than the exception. In early August 2009, for instance, there were over 1.6 million auctions for computer and networking products, over 1.3 million for DVDs, and over 4 million for books (excluding antique and collectible books); on the same day there were just over 200,000 auctions for antiques and just over 260,000 for entertainment memorabilia (source: http://listings.ebay.com/).

In addition, sellers offering large numbers of DVDs probably specialize in the sale of such products (few sellers would be expected to sell both rare dolls, say, and best-seller DVDs), and hence peak-listing is unlikely to usually be an optimal strategy for them.

In terms of generalizability of the findings. Intuitively, excessive entry is more likely to occur in situations where sellers do not receive feedback about the profitability of supplying offpeak. This is likely to occur, for example, in settings where independent small sellers make and observe one or just a few entry decisions, as is the case with owners of small business entrepreneurs (e.g. independent restaurants) or with people's decision of investment in human capital (e.g. deciding what major to study or where to look for work). It is less likely to occur in settings where large firms make repetitive decisions, such as food chains deciding on new locations for their restaurants.

Excess entry into peak demand markets is also likely to occur in industries where a highdemand market is so focal that even large sellers will not have experimented with off-peak demand, as seems to be the case with the movie industry's reluctance to launch blockbuster films on non-peak movie-going weekends (Einav, 2007). 
In closing, this paper demonstrates the importance for marketing research that relies on field data to assess rather than assume the rationality of agents being studied. 


\section{References}

Bajari, P., \& Hortacsu, A. (2004). Economic Insights from Internet Auctions. Journal of Economic Literature, 42(2), 457-486.

Busch, D. D. (2004). The Ebay Myth-Bu\$Ter: Turn 199 Misconceptions into Money! (for Dummies Series) (1st ed.): Wiley.

Camerer, C. F., \& Lovallo, D. (1999). Overconfidence and Excess Entry: An Experimental Approach. American Economic Review, 89(1), 306-318.

Che, H., Sudhir, K., \& Seetharaman, P. B. (2007). Bounded Rationality in Pricing under StateDependent Demand: Do Firms Look Ahead, and If So, How Far? Journal of Marketing Research, 44(3), 434-449.

DellaVigna, S. (forthcoming). Psychology and Economics: Evidence from the Field. Journal of Economic Literature.

DellaVigna, S., \& Pollet, J. (2007). Demographics and Industry Returns. American Economic Review, 97, 1167-1702.

DellaVigna, S., \& Pollet, J. (2009). Investor Inattention and Friday Earnings Announcements, . Journal of Finance, 64, 709-749.

Einav, L. (2007). Seasonality in the U.S. Motion Picture Industry. RAND Journal of Economics, $38(1), 127-145$.

Eisensee, T., \& Strömberg, D. (2007). News Droughts, News Floods, and U.S. Disaster Relief. Quarterly Journal of Economics, 122(2), 693-728.

Goldfarb, A., \& Xiao, M. (2008). Who Thinks About the Competition? Managerial Ability and Strategic Entry in Us Local Telephone Markets.Unpublished manuscript.

Goldfarb, A., \& Yang, B. (Forthcoming). Are All Managers Created Equal? Journal of Marketing Research.

Grisprud, G., \& Gronhaug, K. (1985). Structure and Strategy in Grocery Retailing: A Sociometric Approach. Journal of Industrial Economics, 33, 339-347.

Hirshleifer, D. A., Lim, S. S., \& Teoh, S. H. (forthcoming). Driven to Distraction: Extraneous Events and Underreaction to Earnings News. Journal of Finance.

Hossain, T., \& Morgan, J. (2006). ...Plus Shipping and Handling: Revenue (Non)Equivalence in Field Experiment on Ebay. Advances in Economic Analysis \& Policy, 6(2), Article 3.

Hsee, C. K., Dube, J. P., \& Zhang, Y. (2008). The Prominence Effect in Shanghai Apartment Prices. Journal of Marketing Research, 45(2), 133-144.

Lee, H., \& Malmendier, U. (2008). The Bidder's Curse.Unpublished manuscript.

Milkman, K. L., Rogers, T., \& Bazerman, M. H. (2009). Highbrow Films Gather Dust: TimeInconsistent Preferences and Online Dvd Rentals. Management Science, 55(6), $1047-$ 1059.

Moore, D. A., Oesch, J., M., \& Zietsma, C. (2007). What Competition? Myopic Self Focus in Market Entry Decisions. Organization Science, 18(3), 440-454.

Ockenfels, A., Reiley, D., \& Sadrieh, A. (2006). Online Auctions.Unpublished manuscript, Cambridge, MA.

Porac, J. F., Thomas, H., \& Baden-Fuller, C. (1989). Competitive Groups as Cognitive Communities: The Case of Scottish Knitwear Manufacturers. Journal of Management Studies, 26, 397-416.

Radzevick, J. R., \& Moore, D. A. (2008). Myopic Biases in Competitions. Organizational Behavior and Human Decision Processes, 107(2), 206-218. 
Simonsohn, U. (2006). New Yorkers Commute More Everywhere: Contrast Effects in the Field. The Review of Economics and Statistics, LXXXVIII(1), 1-9.

Simonsohn, U., \& Ariely, D. (2008). When Rational Sellers Face Non-Rational Buyers: Evidence from Herding in Online Auctions. Management Science, 54(9), 1624-1637.

Simonsohn, U., \& Loewenstein, G. (2006). Mistake \#37: The Impact of Previously Observed Prices on Housing Demand. The Economic Journal, 116(1), 175-199.

Wingo, S. (2004). Ebay Strategies: 10 Proven Methods to Maximize Your Ebay Business Prentice Hall. 
Table 1. Descriptive Statistics

\begin{tabular}{|c|c|c|c|c|c|c|c|c|c|}
\hline & $\begin{array}{c}\text { Final price } \\
\text { of sold } \\
\text { items } \\
\end{array}$ & $\begin{array}{c}\text { \# of Bids } \\
\text { received } \\
\text { (per auction) }\end{array}$ & $\begin{array}{c}\begin{array}{c}\text { Percentage } \\
\text { Sold }\end{array} \\
\end{array}$ & $\begin{array}{l}\text { Seller } \\
\text { Rating }\end{array}$ & $\begin{array}{l}\text { Starting } \\
\text { Price }\end{array}$ & $\begin{array}{c}\text { Duration } \\
\text { of auction } \\
\text { in days } \\
\end{array}$ & $\begin{array}{l}\text { Shipping } \\
\text { Charges }\end{array}$ & $\begin{array}{c}\text { Percentage } \\
\text { with reserve } \\
\text { price }\end{array}$ & $\begin{array}{l}\text { Percentage } \\
\text { offered by } \\
\text { stores }\end{array}$ \\
\hline \multicolumn{10}{|c|}{ Single DVDs Sample $(N=11,796)$} \\
\hline Mean & $\$ 10.16$ & 4.68 & $70.8 \%$ & 1,819 & $\$ 7.23$ & 4.78 & $\$ 3.60$ & $0.9 \%$ & $13.9 \%$ \\
\hline Median & $\$ 9.99$ & 3.00 & -- & 495 & $\$ 8.00$ & 5.00 & $\$ 3.50$ & -- & -- \\
\hline Standard Deviation & $\$ 2.80$ & 3.99 & -- & 3,969 & $\$ 4.05$ & 2.17 & $\$ 1.10$ & -- & -- \\
\hline \multicolumn{10}{|c|}{ Multiple DVDs Sample $(N=3,177)$} \\
\hline Mean & $\$ 55.92$ & 9.82 & $89.6 \%$ & 1,511 & $\$ 21.80$ & 4.63 & $\$ 6.40$ & $7.3 \%$ & $11.0 \%$ \\
\hline Median & $\$ 55.00$ & 10.00 & -- & 349 & $\$ 9.99$ & 5.00 & $\$ 6.00$ & -- & -- \\
\hline Standard Deviation & $\$ 26.87$ & 6.30 & -- & 3,184 & $\$ 24.51$ & 2.19 & $\$ 2.26$ & -- & -- \\
\hline
\end{tabular}

Notes: Average final prices and number of bids exclude unsold items. . 
Table 2. Impact of market saturation when auction ends on probability of sale (probit, marginal effects)

Dependent Variable: 1 if auction sold, 0 if it did not.

\begin{tabular}{|c|c|c|c|c|c|c|c|c|}
\hline & (1) & (2) & (3) & (4) & (5) & (6) & (7) & (8) \\
\hline Sample: & \multicolumn{3}{|c|}{ Single DVD (movies) } & \multicolumn{5}{|c|}{$\begin{array}{c}\text { Multiple DVDs (TV Seasons and } \\
\text { Compilations) }\end{array}$} \\
\hline $\begin{array}{l}\text { A/B-ratio } \\
\text { (Auctions/Bids ratio last } 180 \text { minutes of auction) }\end{array}$ & $\begin{array}{l}-0.355^{\star * \star} \\
(0.034)\end{array}$ & $\begin{array}{l}-0.30 * * \star \\
(0.03)\end{array}$ & $\begin{array}{l}-0.289 * \star \star \\
(0.031)\end{array}$ & & $\begin{array}{l}-0.125 \\
(0.102)\end{array}$ & $\begin{array}{l}-0.222^{\star *} \\
(0.090)\end{array}$ & $\begin{array}{l}-0.243^{\star * \star} \\
(0.091)\end{array}$ & \\
\hline $\begin{array}{l}\text { Peak } \\
\text { (equals } 1 \text { if auction ends during one of the four most } \\
\text { popular hours) }\end{array}$ & & & & $\begin{array}{l}-0.077^{\star * *} \\
(0.009)\end{array}$ & & & & $\begin{array}{l}-0.040 * \star \star \\
(0.013)\end{array}$ \\
\hline $\begin{array}{l}\text { Starting Price } \\
\text { (minimum \$ amount of first bid) }\end{array}$ & & $\begin{array}{c}-0.067^{\star \star \star} \\
(0.002)\end{array}$ & $\begin{array}{l}-0.067^{\star \star \star} \\
(0.002)\end{array}$ & $\begin{array}{l}-0.066^{\star \star \star} \\
(0.002)\end{array}$ & & $\begin{array}{l}-0.0026 * \star \star \\
(0.0003)\end{array}$ & $\begin{array}{l}-0.0026^{\star \star \star} \\
(0.0003)\end{array}$ & $\begin{array}{c}-0.0025^{\star \star \star} \\
(0.0003)\end{array}$ \\
\hline $\begin{array}{l}\text { Reservation Price } \\
\text { (secret minimum price at which seller would sell) }\end{array}$ & & $\begin{array}{c}-0.045^{\star \star \star} \\
(0.01)\end{array}$ & $\begin{array}{c}-0.041^{\star \star \star} \\
(0.011)\end{array}$ & $\begin{array}{c}-0.041^{\star \star \star} \\
(0.011)\end{array}$ & & $\begin{array}{l}-0.0021^{\star \star \star} \\
(0.0003)\end{array}$ & $\begin{array}{l}-0.0021^{\star \star \star} \\
(0.0003)\end{array}$ & $\begin{array}{c}-0.0020^{* \star \star} \\
(0.0003)\end{array}$ \\
\hline $\begin{array}{l}\text { Shipping charges } \\
\text { (set by seller) }\end{array}$ & & $\begin{array}{l}-0.034^{\star \star *} \\
(0.004)\end{array}$ & $\begin{array}{l}-0.028^{\star \star \star} \\
(0.004)\end{array}$ & $\begin{array}{l}-0.026^{\star * \star} \\
(0.004)\end{array}$ & & $\begin{array}{l}-0.0083^{\star \star \star} \\
(0.0021)\end{array}$ & $\begin{array}{l}-0.0079^{* * *} \\
(0.0021)\end{array}$ & $\begin{array}{l}-0.0081^{\star \star \star} \\
(0.0020)\end{array}$ \\
\hline $\begin{array}{l}\text { Duration of auction (days) } \\
\text { (auctions last } 3,5,7 \text { or } 10 \text { days) }\end{array}$ & & $\begin{array}{l}0.0076^{\star \star \star} \\
(0.002)\end{array}$ & $\begin{array}{l}0.007^{\star * \star} \\
(0.002)\end{array}$ & $\begin{array}{l}0.008^{\star \star \star} \\
(0.002)\end{array}$ & & $\begin{array}{r}0.0031 \\
(0.0020)\end{array}$ & $\begin{array}{r}0.0033 \\
(0.0021)\end{array}$ & $\begin{array}{r}0.0030 \\
(0.0020)\end{array}$ \\
\hline $\begin{array}{l}\text { Weekend dummy } \\
\text { (equals } 1 \text { if auction ends on a weekend) }\end{array}$ & & $\begin{array}{l}0.019^{* *} \\
(0.009)\end{array}$ & $\begin{array}{l}0.019^{\star *} \\
(0.009)\end{array}$ & $\begin{array}{r}0.005 \\
(0.009)\end{array}$ & & $\begin{array}{l}0.0246^{\star \star *} \\
(0.0092)\end{array}$ & $\begin{array}{l}0.0250^{* * *} \\
(0.0092)\end{array}$ & $\begin{array}{l}0.0187^{\star *} \\
(0.0089)\end{array}$ \\
\hline $\begin{array}{l}\text { Log(seller rating }+1) \\
\text { (seller rating: sum of }+1,0-1 \text { feedback scores) }\end{array}$ & & & $\begin{array}{l}0.027^{\star \star \star} \\
(0.003)\end{array}$ & $\begin{array}{l}0.028^{\star \star \star} \\
(0.003)\end{array}$ & & & $\begin{array}{l}-0.0007 \\
(0.0022)\end{array}$ & $\begin{array}{l}-0.0004 \\
(0.0023)\end{array}$ \\
\hline $\begin{array}{l}\text { Store Dummy } \\
\text { (equals } 1 \text { if seller has contract with eBay) }\end{array}$ & & & $\begin{array}{l}-0.092^{\star * \star} \\
(0.017)\end{array}$ & $\begin{array}{l}-0.088^{\star \star \star} \\
(0.017)\end{array}$ & & & $\begin{array}{l}-0.0453^{\star \star} \\
(0.0184)\end{array}$ & $\begin{array}{l}-0.0465^{\star \star} \\
(0.0185)\end{array}$ \\
\hline DVD Title Fixed Effects & Yes & Yes & Yes & & Yes & Yes & Yes & Yes \\
\hline New dummy * DVD title & No & Yes & Yes & & No & Yes & Yes & Yes \\
\hline $\begin{array}{r}\text { Implied marginal effect on pr(sale) of } \\
\text { ending on peak (vs.off peak) }\end{array}$ & $-6.9 \%$ & $-5.9 \%$ & $-5.5 \%$ & $-7.7 \%$ & $-2.1 \%$ & $-3.8 \%$ & $-4.1 \%$ & $-4.0 \%$ \\
\hline Number of observations & 11,695 & 11,695 & 11,695 & 11,695 & 2,937 & 2,937 & 2,937 & 2,937 \\
\hline
\end{tabular}

Notes: Entries in table correspond to marginal effects estimated at sample means (i.e. impact on dependent variable of increasing independent variable in one unit) obtained employing a probit regression. Robust standard errors reported in parenthesis below marginal effects. A/B ratio is the ratio of percentage of daily auctions ending during auction's last 180 minutes, to the percentage of daily bids over the same time period.

$*, * *, * * *$ indicates significance at the $10 \%, 5 \%$ and $1 \%$ level respectively 
Table 3. Impact of market saturation when auction ends on selling prices.

Dependent Variable: Selling price (censored at starting price for Tobit regressions)

\begin{tabular}{|c|c|c|c|c|c|c|c|c|c|c|}
\hline & (1) & (2) & (3) & (4) & (5) & (6) & (7) & (8) & (9) & (10) \\
\hline Sample: & \multicolumn{5}{|c|}{ Single DVD (movies) } & \multicolumn{5}{|c|}{ Multiple DVDs } \\
\hline Regression Type: & Tobit & Tobit & Tobit & OLS & Tobit & Tobit & Tobit & Tobit & OLS & Tobit \\
\hline $\begin{array}{l}\text { A/B-ratio } \\
\text { (Auctions/Bids ratio auction's last } 180 \mathrm{~min} \text {.) }\end{array}$ & $\begin{array}{l}-0.828^{\star \star *} \\
(0.143)\end{array}$ & $\begin{array}{l}-1.066^{\star * \star} \\
(0.116)\end{array}$ & $\begin{array}{l}-1.017^{\star \star \star} \\
(0.115)\end{array}$ & $\begin{array}{l}-\mathbf{0 . 6 8 3 * * *} \\
(0.179)\end{array}$ & & $\begin{array}{l}-13.903^{\star * \star} \\
(4.368)\end{array}$ & $\begin{array}{l}-17.270 * \star \star \\
(4.913)\end{array}$ & $\begin{array}{l}-18.971^{\star \star \star} \\
(4.909)\end{array}$ & $\begin{array}{l}-16.003^{\star \star *} \\
(5.240)\end{array}$ & \\
\hline $\begin{array}{l}\text { Peak } \\
\text { (equals } 1 \text { if auction ends during one of the } \\
\text { four most popular hours) }\end{array}$ & & & & & $\begin{array}{l}-0.273^{\star \star \star} \\
(0.030)\end{array}$ & & & & & $\begin{array}{l}-2.924^{\star \star *} \\
(0.666)\end{array}$ \\
\hline $\begin{array}{l}\text { Starting Price } \\
\text { (minimum \$ amount of first bid) }\end{array}$ & & $\begin{array}{l}0.033^{\star \star \star} \\
(0.006)\end{array}$ & $\begin{array}{l}0.040^{\star \star \star} \\
(0.006)\end{array}$ & $\begin{array}{l}0.129 * \star \star \\
(0.010)\end{array}$ & $\begin{array}{l}0.041^{\star \star *} \\
(0.006)\end{array}$ & & $\begin{array}{l}0.125^{\star \star \star} \\
(0.002)\end{array}$ & $\begin{array}{l}0.120^{\star \star \star} \\
(0.002)\end{array}$ & $\begin{array}{l}0.071^{\star \star \star} \\
(0.012)\end{array}$ & $\begin{array}{l}0.124^{\star \star \star} \\
(0.002)\end{array}$ \\
\hline $\begin{array}{l}\text { Reservation Price } \\
\text { (secret minimum price at which seller would sell) }\end{array}$ & & $\begin{array}{r}0.077 \\
(0.065)\end{array}$ & $\begin{array}{l}0.107^{\star} \\
(0.063)\end{array}$ & $\begin{array}{l}0.415^{\star \star \star} \\
(0.139)\end{array}$ & $\begin{array}{l}0.106^{\star} \\
(0.063)\end{array}$ & & $\begin{array}{l}0.077^{\star * \star} \\
(0.017)\end{array}$ & $\begin{array}{l}0.084 * \star \star \\
(0.016)\end{array}$ & $\begin{array}{l}0.077^{\star \star \star} \\
(0.016)\end{array}$ & $\begin{array}{l}0.087^{\star \star \star} \\
(0.017)\end{array}$ \\
\hline $\begin{array}{l}\text { Shipping charges } \\
\text { (set by seller) }\end{array}$ & & $\begin{array}{l}-0.272^{\star \star \star} \\
(0.021)\end{array}$ & $\begin{array}{l}-0.246^{\star \star \star} \\
(0.021)\end{array}$ & $\begin{array}{l}-0.355^{\star \star \star} \\
(0.036)\end{array}$ & $\begin{array}{l}-0.243^{\star \star \star} \\
(0.021)\end{array}$ & & $\begin{array}{l}-0.706^{\star \star \star} \\
(0.128)\end{array}$ & $\begin{array}{l}-0.752^{\star \star \star} \\
(0.128)\end{array}$ & $\begin{array}{l}-0.606 * \star \star \\
(0.112)\end{array}$ & $\begin{array}{l}-0.776^{\star \star \star} \\
(0.128)\end{array}$ \\
\hline $\begin{array}{l}\text { Duration of auction (days) } \\
\text { (auctions last } 3,5,7 \text { or } 10 \text { days) }\end{array}$ & & $\begin{array}{l}0.058^{\star \star \star} \\
(0.001)\end{array}$ & $\begin{array}{l}0.057^{\star \star \star} \\
(0.001)\end{array}$ & $\begin{array}{l}0.068^{\star \star \star} \\
(0.011)\end{array}$ & $\begin{array}{l}0.058^{\star \star \star} \\
(0.001)\end{array}$ & & $\begin{array}{l}0.612^{* * *} \\
(0.117)\end{array}$ & $\begin{array}{l}0.609 * * \star \\
(0.116)\end{array}$ & $\begin{array}{l}0.203^{\star \star \star} \\
(0.074)\end{array}$ & $\begin{array}{l}0.599 * \star \star \\
(0.115)\end{array}$ \\
\hline $\begin{array}{l}\text { Weekend dummy } \\
\text { (equals } 1 \text { if auction ends on a weekend) }\end{array}$ & & $\begin{array}{l}-0.040 \\
(0.031)\end{array}$ & $\begin{array}{l}-0.043 \\
(0.030)\end{array}$ & $\begin{array}{l}-0.163^{\star \star *} \\
(0.047)\end{array}$ & $\begin{array}{l}-0.089 * \star \star \\
(0.030)\end{array}$ & & $\begin{array}{l}1.084^{\star *} \\
(0.479)\end{array}$ & $\begin{array}{l}1.041^{\star *} \\
(0.476)\end{array}$ & $\begin{array}{l}-0.308 \\
(0.373)\end{array}$ & $\begin{array}{r}0.449 \\
(0.416)\end{array}$ \\
\hline $\begin{array}{l}\text { Log(seller rating }+1) \\
\text { (seller rating: sum of }+1,0-1 \text { feedback scores) }\end{array}$ & & & $\begin{array}{l}0.198^{\star \star \star} \\
(0.011)\end{array}$ & $\begin{array}{l}0.267^{\star * \star} \\
(0.015)\end{array}$ & $\begin{array}{l}0.201^{\star \star *} \\
(0.011)\end{array}$ & & & $\begin{array}{l}0.691 * \star \star \\
(0.112)\end{array}$ & $\begin{array}{l}0.653^{\star \star \star} \\
(0.095)\end{array}$ & $\begin{array}{l}0.725^{\star \star \star} \\
(0.114)\end{array}$ \\
\hline $\begin{array}{l}\text { Store Dummy } \\
\text { (equals } 1 \text { if seller has contract with eBay) }\end{array}$ & & & $\begin{array}{l}-0.144^{\star \star \star} \\
(0.048)\end{array}$ & $\begin{array}{l}-0.024 \\
(0.074)\end{array}$ & $\begin{array}{l}-0.134^{\star \star \star} \\
(0.048)\end{array}$ & & & $\begin{array}{l}-0.919 \\
(0.636)\end{array}$ & $\begin{array}{l}-0.246 \\
(0.511)\end{array}$ & $\begin{array}{l}0.642^{\star \star \star} \\
(-1.600)\end{array}$ \\
\hline DVD Title Fixed Effects & Yes & Yes & Yes & Yes & Yes & Yes & Yes & Yes & Yes & Yes \\
\hline New dummy * DVD title & Yes & Yes & Yes & Yes & Yes & Yes & Yes & Yes & Yes & Yes \\
\hline $\begin{array}{r}\text { Implied marginal effect on price of } \\
\text { ending on peak (vs.off peak) }\end{array}$ & $-\$ 0.16$ & $-\$ 0.21$ & $-\$ 0.20$ & $-\$ 0.13$ & $-\$ 0.27$ & $-\$ 2.39$ & $-\$ 2.97$ & $-\$ 3.26$ & $-\$ 2.75$ & $-\$ 2.92$ \\
\hline Number of observations & 11,796 & 11,796 & 11,796 & 8,355 & 11,796 & 3,177 & 3,177 & 3,177 & 2,849 & 3,177 \\
\hline
\end{tabular}

Notes: Entries in columns 1-3 and 5-7 correspond to marginal effects (E[price|XB,price>starting price]) from Tobit regressions where final prices of unsold auctions are considered censored at the auction's starting-price. Entries in columns 4 and 8 are point estimates from OLS regressions that exclude unsold auctions. Robust standard errors reported in parenthesis below parameter estimates. A/B ratio is the ratio of percentage of daily auctions ending during auction's last 180 minutes, to the percentage of daily bids (counting only one bid per bidder per auction) over the same time period.

$*, * *, * *$ indicates significance at the $10 \%, 5 \%$ and $1 \%$ level respectively 
Figure 1. Extent of late bidding by hour of day.

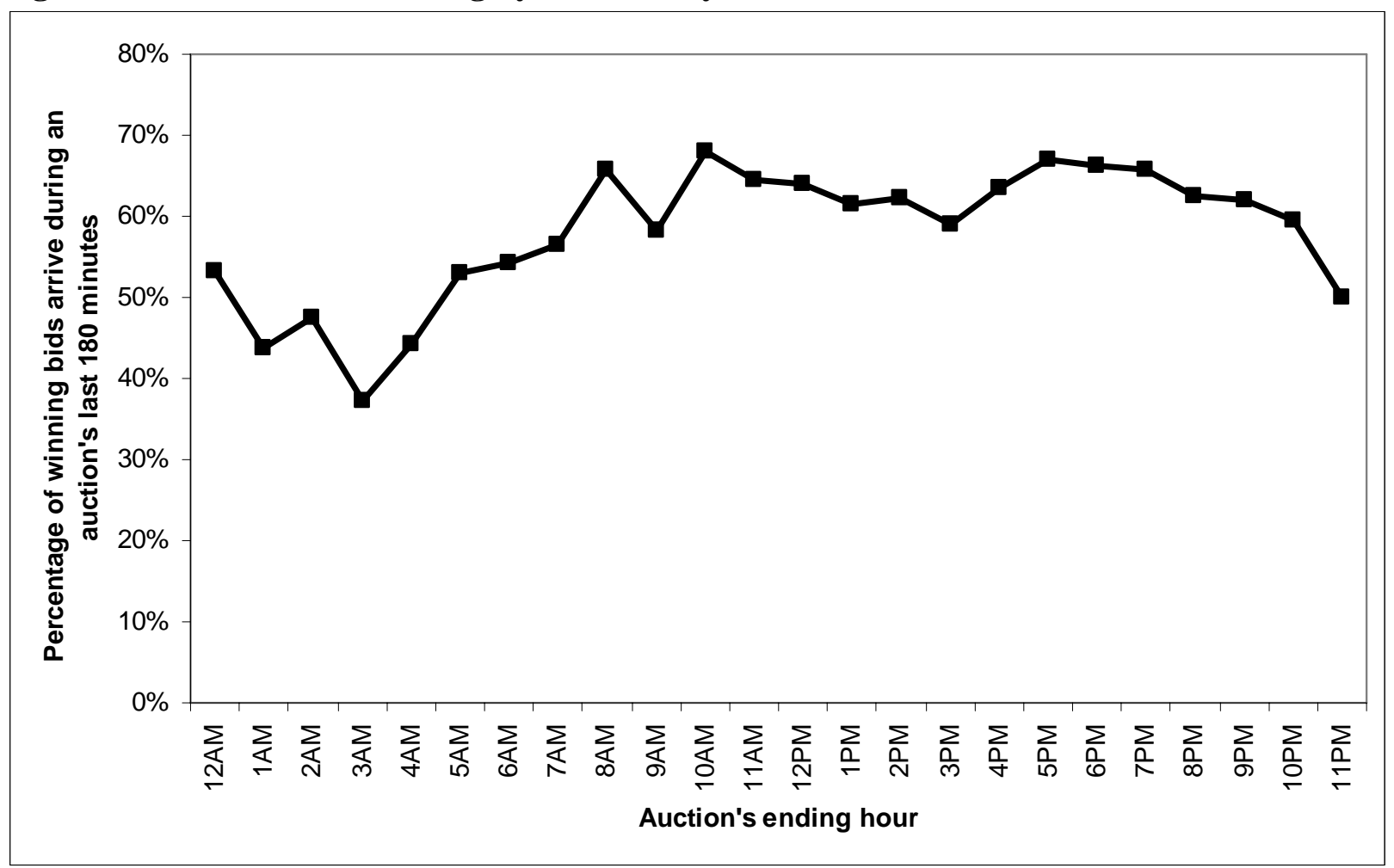

Notes: The figure shows the fraction of winning bids arriving within an auction's last 180 minutes. There are 11,531 observations depicted in the figure (auctions receiving 0 bids are excluded). Less than $7 \%$ of auctions depicted in the figure end between 12AM and 7AM. 
Figure 2a. Percentage of daily auctions ending, and daily bids placed, by hour

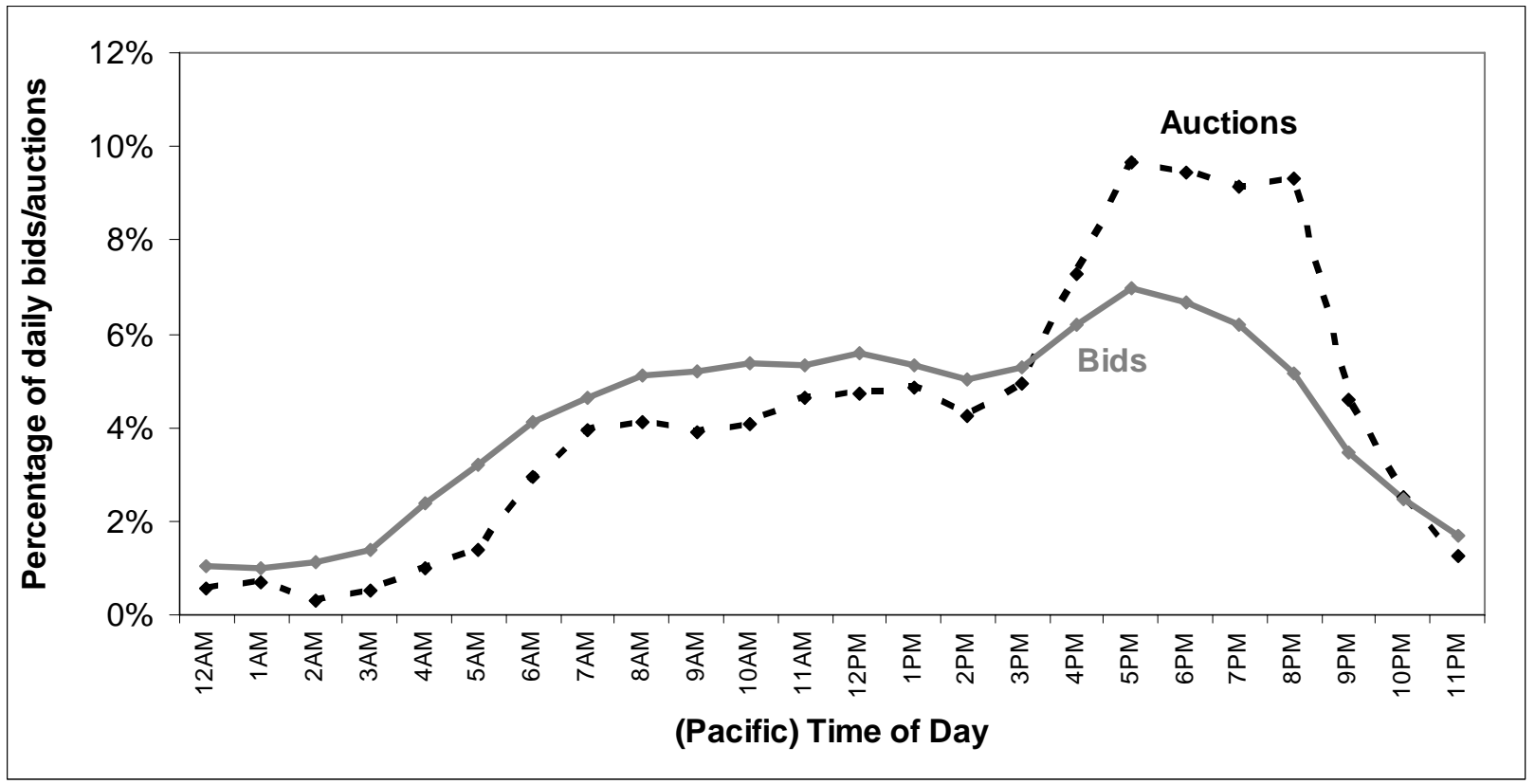

Notes: The figure depicts the percentage of auctions in the single and multiple-DVD samples combined $(\mathrm{N}=14,973)$ ending at each hour of the day, and the percentage of bids placed by hour $(\mathrm{N}=44,735)$. Multiple bids by the same bidder on the same auction are excluded, keeping only a bidder's last bid. 
Figure $2 b$. Hourly ratio of $\%$ of auctions ending over $\%$ of bids placed

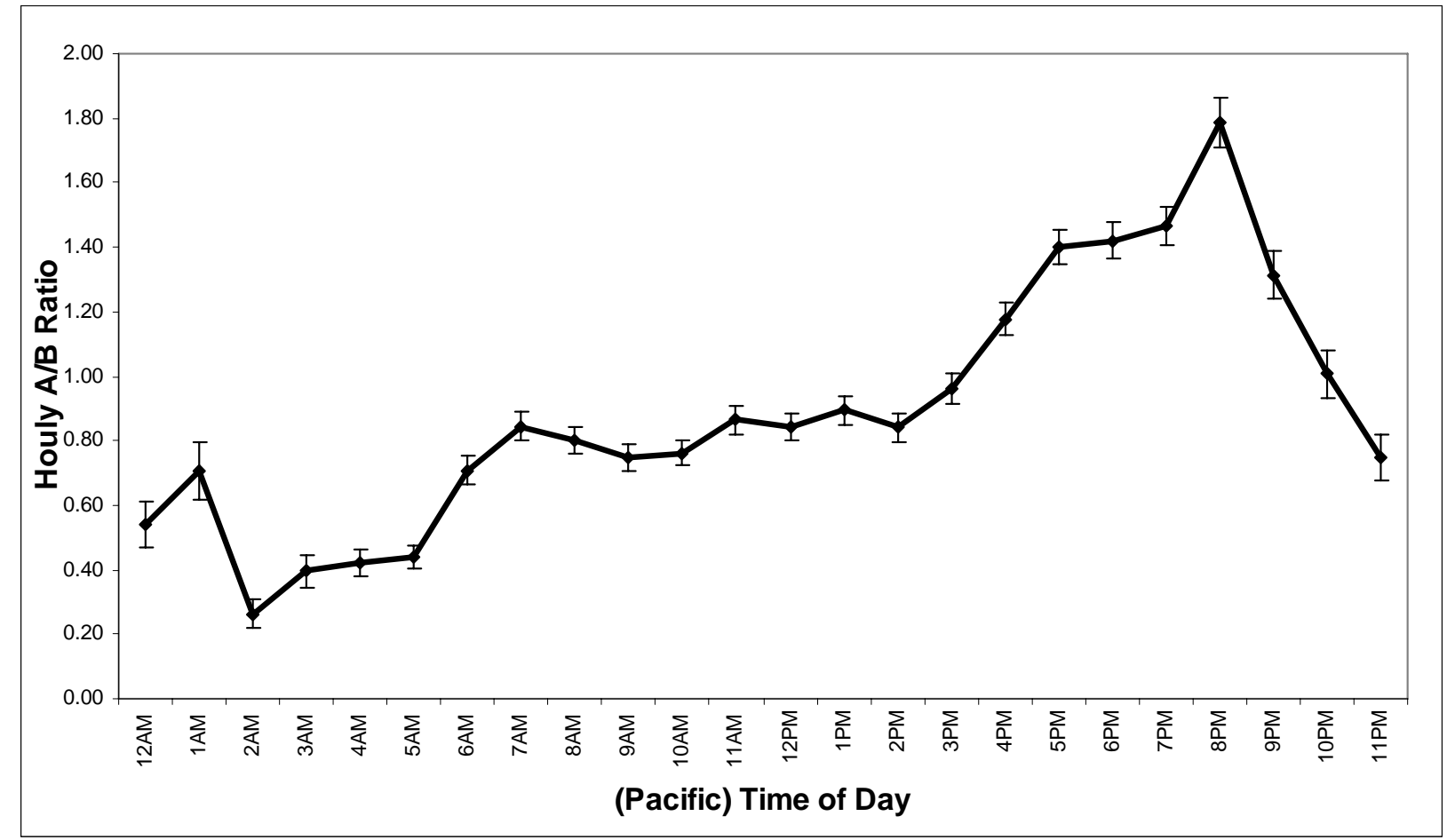

Notes: The figure depicts the ratio of the percentage of auctions in the single and multiple-DVD samples combined $(\mathrm{N}=14,973)$ ending at each hour of the day over the the percentage of bids placed by hour $(\mathrm{N}=44,735)$.

Multiple bids by the same bidder on the same auction are excluded, keeping only a bidder's last bid. Vertical bars show standard error computed with the Delta Method. 
Figure 3. Experience increases peak-listing but not peak-bidding.

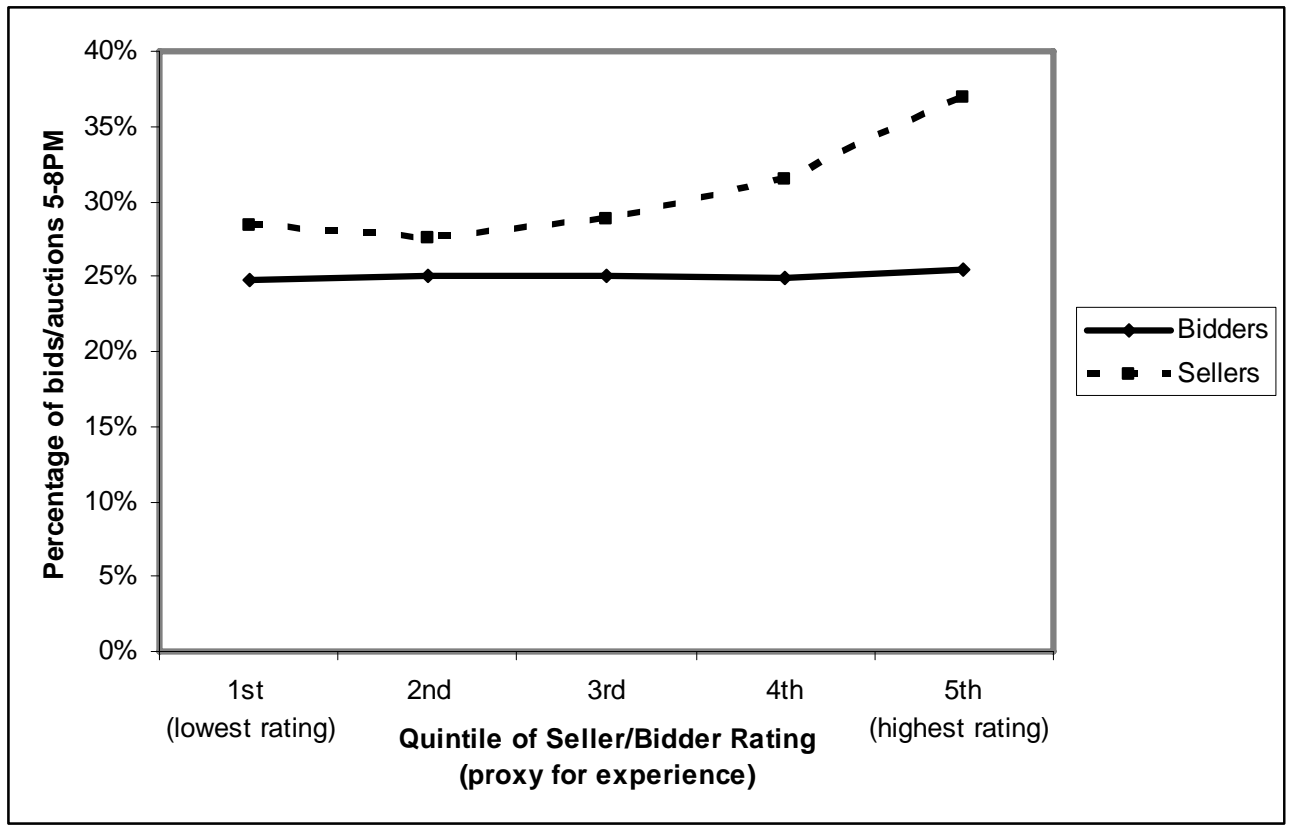

Notes: Lines plot the percentage of all auctions set to end during the 5-8PM period, and bids placed during such hours, by quintile of seller and bidder experience, respectively, proxied by feedback score. 
Figure 4. Sellers consistently ending auctions at the same time are more likely to end them during the peak

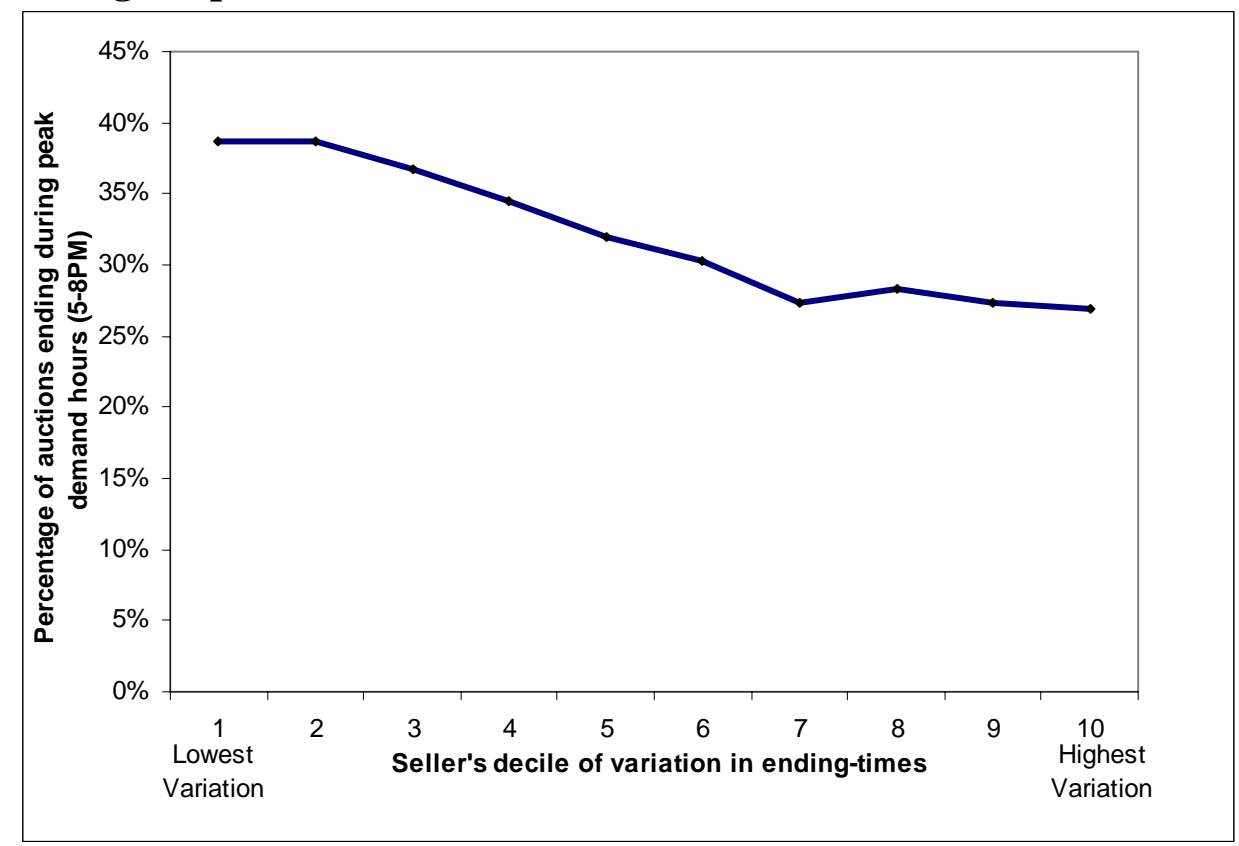

Notes: Figure plots percentage of auctions ending during the peak (in one half of month), listed by sellers within each decile of variation in ending-times (during the other half). 
Figure 5. Time of day, probability of sale and prices (Single-DVD sample)

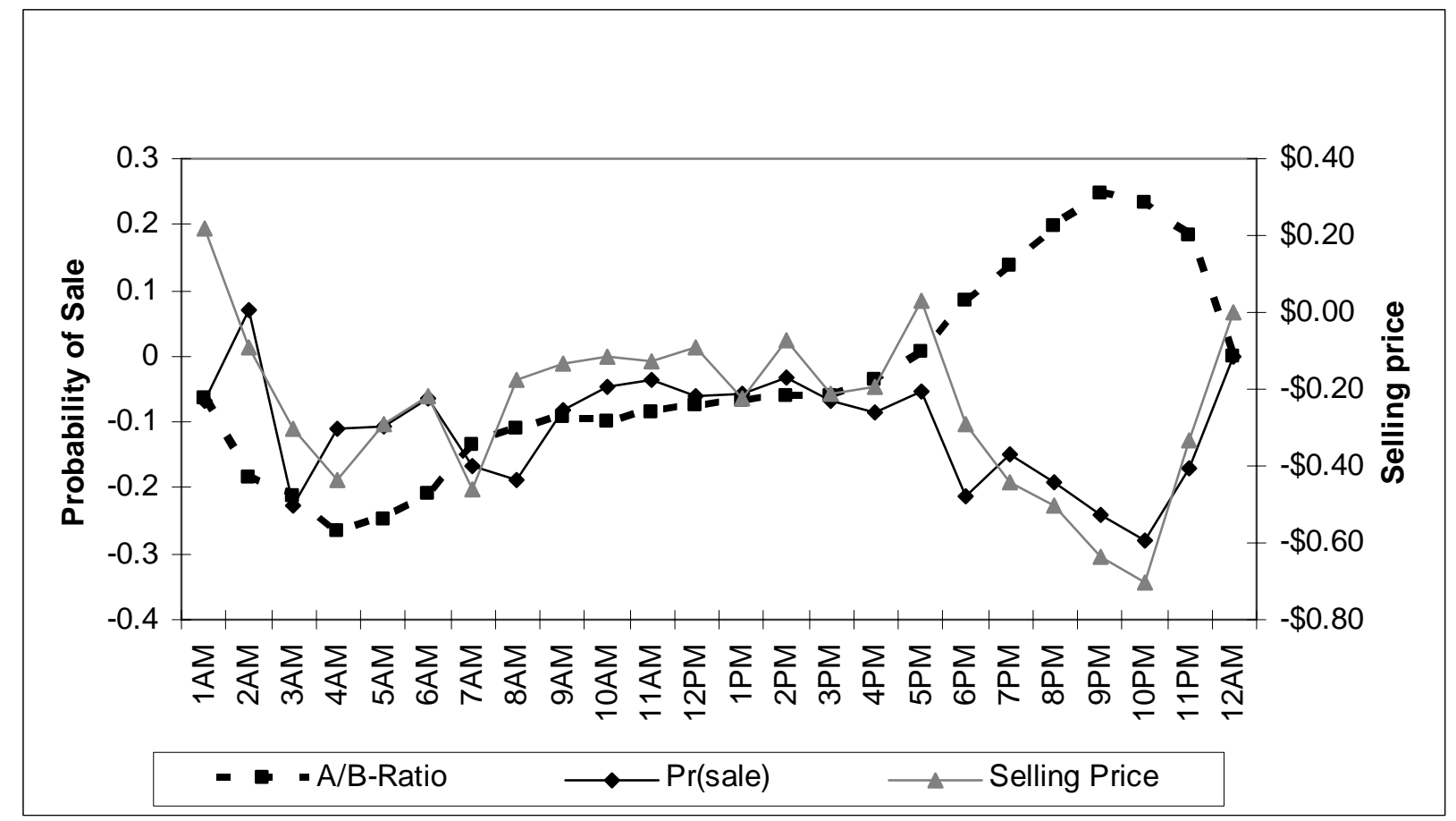

Notes: For Pr(sale) and Selling Price the lines plot the point estimates for hourly dummies in Probit and Tobit regressions respectively, controlling for all observables listed in Tables $2 \& 3 .(\mathrm{N}=11,796)$. The auctions-to-bids ratio (A/B-ratio) has been rescaled to fit into existing Y-index, it lacks an absolute meaning in this figure. 
Figure 6. Time of day, probability of sale and prices (Multiple-DVD sample)

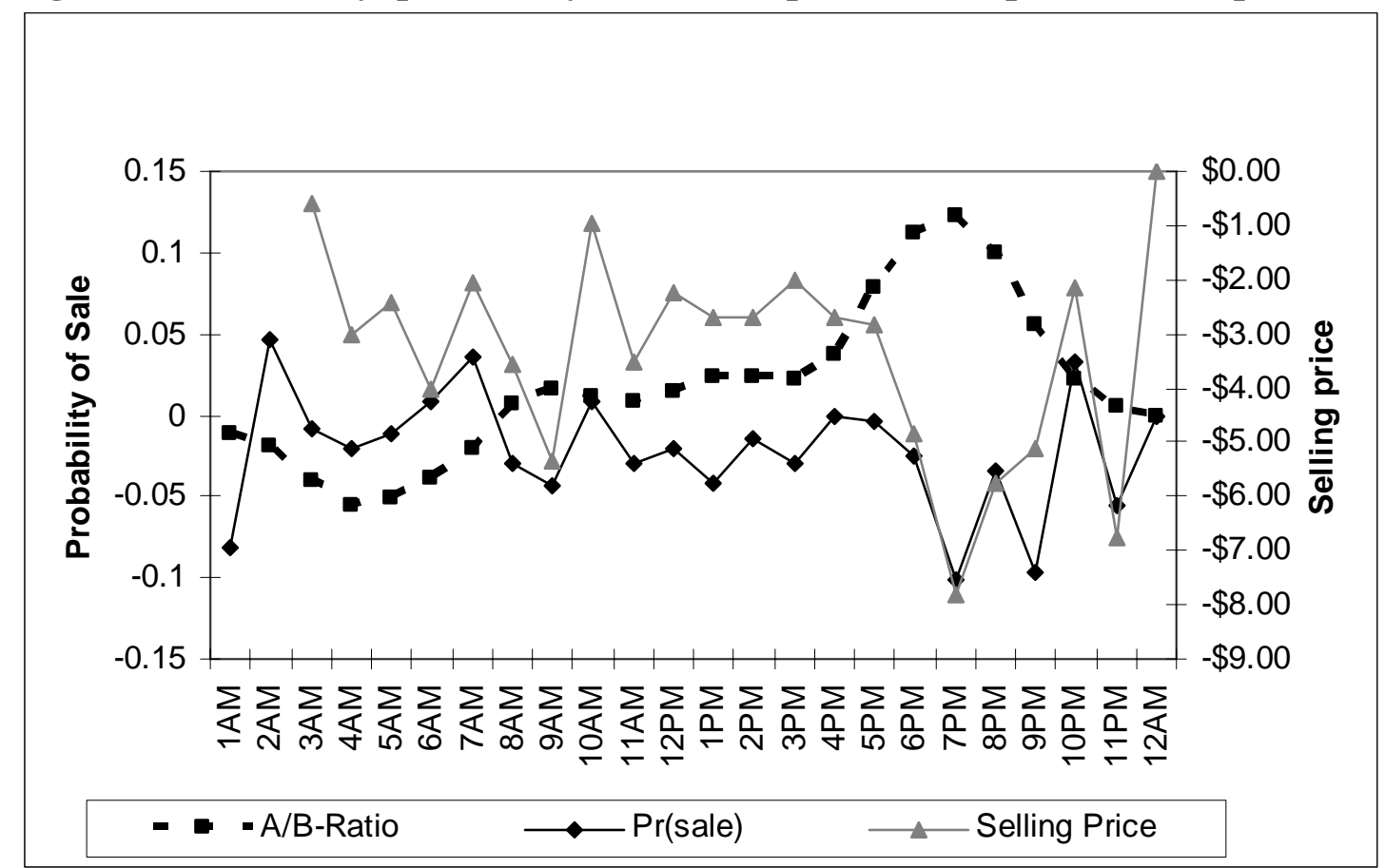

Notes: For probability of sale $(\operatorname{Pr}($ sale $))$ and Selling Price the lines plot the point estimates for hourly dummies in Probit and Tobit regressions respectively, controlling for all observables listed in Tables $2 \& 3(\mathrm{~N}=3,117)$. The auctions-to-bids ratio (A/B-Ratio) has been rescaled to fit into existing Y-index, it lacks an absolute meaning in this figure. 
As was mentioned in the data description, eBay does not utilize unique product identifiers for their listings, so bidders and researchers must rely on sellers' descriptions of their items to identify what's being auctioned. Bidders can easily do this because they see but a handful of auctions, which furthermore, they come across only after querying relevant keywords themselves.

As a researcher interested in identifying several thousand items, in contrast, I had to develop an at least partially automatized process to do this. To this end I selected a set of DVD titles against which the seller descriptions were to be automatically compared (see Appendix B for details on the selection of such titles).

For each movie title I chose a few keywords to search in the descriptions of each of the over 500,000 auctions in the DVD category. For example, for the movie "A walk to remember," items whose descriptions contained the keywords "walk" and "remember" where initially classified as such movie.

Because different movies often have similar names this initial process lead to a nontrivial share of false positives which included completely different movies with similar names, closely related films (e.g. sequels and remakes) and different DVD versions of the same original movie.

In order to systematically identify these false-positives I tabulated, for each movie, all words used in the descriptions of all items. The resulting list was then inspected "by hand" for suspicious words that may indicate a false-positive.

For example, among auctions categorized as "Gladiator" (the Oscar winning film) the word "Eroticvs" appeared 5 times. By reading the full description of the corresponding listings I 
discovered the existence of the film "Gladiator Eroticvs", a different movie altogether. The word "Jurassic" also appeared on a few other descriptions of auctions identified as "Gladiator". Upon examining their full descriptions, it was determined that these auctions offered a bundle which included two films: Gladiator and Jurassic Park. Finally, the high frequency of the word "Signature" pointed to the fact that there were -at the time- two versions of "Gladiator", a standard one (containing 2 DVDs) and a "Signature Series" one (containing 3). For this process I supplemented my personal movie knowledge with the websites Amazon.com, IMDB.com, and DVDcompare.net. ${ }^{15}$

This process is obviously very time intensive. Because the time it takes to identify false positives is relatively fixed per movie title rather than per auction, I constructed the subsamples based on popular titles; that way a maximum number of observations was obtained with a given amount of time devoted to data-cleaning. Not a single classification or exclusion was made based on the impact of excluding that/those observation(s) from the sample on the regression results.

\footnotetext{
${ }^{15}$ DVDcompare.net provides detailed information on different DVD versions of the same movie.
} 
The single-DVD list of movies corresponds to movies appearing on a weekly top-20 list in the Internet Movie Database archive (http://www.imdb.com) at least once during the two months immediately before the sample's month or listed as the top-20 bestsellers for the previous year.

I am not aware of any best-seller list for multiple-DVD sets. To identify common titles I tabulated the word frequency of auctions selling for more than $\$ 30$. I eliminated all words used less than 100 times, and also eliminated those that were generic descriptors rather than movie title identifiers (e.g., 'DVD', 'NEW', 'shipping', etc). The list of words that remained were then used to uncover titles of multiple-DVD sets often sold on eBay. 